\title{
Ekonomik Karar Almada Adalet Ve Oyun Teorisi
}

Murat Yalçıntaș'

Makale Gönderim Tarihi: 16.12.2014

Makale Kabul Tarihi: 26.02.2015

\section{öz}

Davranıs bilimlerindeki ekonomik karar verme mekanizmalarının incelenmesinde sıklıkla bașvurulan oyun teorisi modellemelerinden biri ültimatom oyunudur. Adam Smith'ten bu yana geleneksel ekonomik teori, bireyin karar verirken öncelikle kendi menfaatini öne çıkardığını kabul eder. Fakat ültimatom oyunu modellemesiyle yapılan pek çok deney, bireyin ekonomik karar verirken, kendi menfaatini azami hale getirmekten ziyade, adalet kavramına uygun hareket etmeyi tercih ettiğini göstermiștir. Bu çaIıșmanın amacı, ekonomik bir karar modellemesi olan ültimatom oyunundaki adalet algısını incelemek ve ekonomik davranıșa etki eden unsurlarını belirlemektir.

Anahtar Sözcükler: Oyun teorisi, ültimatom oyunu; ekonomik karar alma; adalet

\section{ABSTRACT}

One of the models used in game theory is the ultimatum game, which has frequently been resorted to in the examination of economic decision-making mechanisms in the behavioral sciences. Since Adam Smith, traditional economic theory has acknowledged that individual agents focus more on expected utility in the decision-making process. However, many case studies conducted by using ultimatum game theory have demonstrated that many

1 İstanbul Ticaret Üniversitesi, İngilizce İșletme Bölümü myalcintas@ticaret.edu.tr 
individuals preferred to act with considerations such as fairness, rather than maximizing expected utility in the economic decision-making process. The purpose of this study is to examine the perception of fairness in the ultimatum game, as well as determining the factors, which have an overall impact on the economic behavior.

Keywords: Game theory, ultimatum game; economic decision-making; fairness

\section{Gíriș}

Adam Smith'ten bu yana geleneksel ekonomik teori bireyin karar verirken öncelikle kendi menfaatini öne çıkardığını kabul eder. Fakat deneysel ekonominin bulguları, insanların klasik ekonominin öngördüğ̈̈ kadar egoist davranmadığını göstermiștir. Bu çerçevede en kapsamlı netice veren araștırmalar, oyun teorisi kapsamındaki ültimatom oyunu kullanılarak yapılan çalıșmalardır.

Ültimatom oyununda birinci oyuncu ikinci oyuncuya belli bir miktar paranın ne șekilde paylașılacağını teklif eder. Eğer ikinci oyuncu teklifi kabul ederse, para öngörüldüğü șekilde paylașılır. Eğer ikinci oyuncu teklifi reddederse iki oyuncu da hiçbir șey alamaz. Geriye doğru çıkarım (tümevarım) ikinci oyuncunun her teklifi kabul edeceğini tahmin eder. Birinci oyuncu da, ikinci oyuncunun bu șekilde akıl yürüteceğini tahmin edip, ona en küçük rakamı teklif eder. Ama klasik oyun teorisinin bu yaklașımı oyun teorisi deneylerinde geçerli çıkmamıșıı. Örneğin, ilk ültimatom oyunu deneylerinde (Güth, Śchmittberger, \& Schwarze, 1982) birinci oyuncu ikinciye paylașlacak miktarın ortalamada \%36.7'sini teklif etmiștir. Yapılan çalıșmalar bu yaklașımın bir kısmının adalet algısından, bir kısmının da yapılacak çok düșük tekliflerin reddedileceği endișesinden olduğunu ortaya çıkarmıștır (Suleiman, 1996).

Ültimatom oyunu çok basit bir oyun olmakla beraber, daha karmașık oyunların modellenmesinde ilk adımdır. Ayrıca basitliği dolayısı ile, neticelerin çok açık bir șekilde analiz edilmesine imkan verir. Böylece maddi menfaatin (paranın) insanın kendisiyle bașkaları arasındaki paylașımında neler hissettiği ölçülebilir (Camerer, 2003, s. 9). 
Oyun teorisi alanındaki gelișmeler, özellikle Nash'in ișbirliksiz oyunlar üzerindeki çalıșmaları, ekonomik teorinin gelișmesine yeni bir istikamet vermiștir (Myerson, 1999). Myerson'a göre, Nash dengesi formülasyonu sosyal bilimler ve ekonomi tarihinde bir dönüm noktasıdır, biyolojideki DNA ikili sarmalın keșfine benzer temel ve yayılmacı bir etkisi olmuștur.

Ültimatom oyunu, insanların ekonomik kararları nasıl aldıklarını basit ama etkili bir biçimde analiz etmemize imkan tanır. Bu çerçevede ültimatom oyununun deneysel ekonomide kullanılması ve sonuçların rasyonel oyun teorisi tahminlerine uymaması, evrimsel oyun teorisi kavramının geliștirilmesine ve ekonomi biliminin yeni bir biçim almasına yol açmıștır (Rizvi, 2003).

Bu makalenin amacı, bireydeki adalet temelli davranıșı hangi unsurların etkilediğini, ültimatom oyunu deneylerini inceleyerek tespit etmektir. Bu çerçevede, insanın ekonomik karar verirken sadece kendi maddi çıkarını değil, belli bir adalet kaygısını da gözettiğini bulgulayan deneysel ekonomi ve evrimsel oyun teorisi çalıșmalarından yola çıkılmıștır.

Makalede önce oyun teorisi, gelișimi ve ekonomik teoriye ne șekilde yön verdiği anlatılmıștır. Nash dengesinin bulunması ve ișbirliksiz oyun teorisindeki gelișmelerin uygulamalı iktisat çaııșmalarının alanını genișletmesi bu bölümde açıklanmıștır. Ayrıca ekonominin klasik fayda teorisi temelli yaklașımdan, toplumdaki rekabetçi davranıșı inceleyen bir bilim haline evrildiği belirtilmiștir.

Takip eden bölümde, ültimatom oyunu açıklanmıștır. Ültimatom oyunu, klasik iktisat teorisinin yaklașımına paralel olarak, insanların akılcı olduğunu ve kendi maddi çıkarlarını düșünerek karar verdiğini varsayar. Ültimatom oyunu ile yapılan deney sonuçlarının klasik ekonomi teorisinin varsayımlarına uymaması, insanların ekonomik kararlar alırken kendi maddi çıkarından bașka unsurların da kararını etkilediğini göstermiștir. Bilim insanları, bu unsurun adalet kavramı olabileceği sonucuna varmıștır.

Daha sonra, adalet kavramı ve bu kavramın bireyin aldığı ekonomik kararlara ne șekilde etki ettiği incelenmiștir. Bu çerçevede, ültimatom oyunu deneylerinin sonuçları irdelenerek, kișinin 
ekonomik karar alırken etkisinde kaldığı unsurlar belirlenmiștir. Bu unsurların en önemlileri; hakkında karar verilecek meblağın miktarı, karar veren kișinin kültürel altyapısı, kișinin toplumdan beklentisi, kișinin karșısındakinden algıladığı niyet ve beklediği davranıș, kișinin tercih ettiği davranıș modeli ve kișinin idrak derecesidir. Bunların yanında, varlığını sürdürme ihtiyacı ve ekonomi bilimi hakkında bilgi sahibi olmak gibi etmenlerin ya hiç etkisinin olmadığı ya da sınırlı etkisinin olduğu, fakat fiziksel güzelliğin önemli olduğu gözlenmiștir.

Çalıșmanın sonuç bölümünde, bulgular tablo haline getirilerek özetlenmiș ve neticeler irdelenmiștir.

\section{Oyun Teorisi ve Ekonomik Teoriye Etkisi}

Oyun teorisi iki veya daha fazla kiși / kurumun (oyuncular) birinin hareketinin sonucunun, sadece kendi hareketine değil, diğer oyuncuların da hareketlerine bağlı olduğu durumları analiz etmek için kullanılan bir tekniktir (Carmichael, 2005, s. 3). Bu durumda oyuncuların stratejileri diğer oyuncuların olası hareketlerine bağlı olacaktır. Oyuncuların kararlarının karșılıklı bağımlı olmasına stratejik bağımlılık, bu tür durumlara da, stratejik oyun veya sadece oyun denir.

Bu çerçeveden bakıldığında, oyun teorisi farklı bilim dallarında farklı biçimlerde kullanılabilir hatta insan hayatı dahi bir oyun olarak kabul edilebilir. Her birey, diğer bireylerle karșılıklı bağımlılık içinde kararlar alır, ulașmak istediği hedefler, bu hedeflere ulașmak için kullandığı stratejiler ve hedeflerine ulaștığında da elde ettiği neticeler vardır. İnsanoğlunun yürüdüğü yol, bazen diğer insanlarla ișbirliğine girmesini, bazen de çatıșmasını gerektirir. Dolayısı ile insanların etkileșim içinde olduğu her durum oyun teorisinin konusu içindedir ve yukarıdaki kavramlar da oyun teorisinin birer parçasıdır.

Tenis oyuncusunun servisi köșeye mi ortaya mı atacağı, pazarlık eden tarafların ne zaman geri adım atacağı, trafikte sıkıșan sürücülerin hangi yolu seçecekleri, firmaların yeni geliștirdikleri ürünü hangi fiyattan piyasaya süreceği, petrol üreticisi ülkelerin petrol fiyatına karar vermeleri gibi birçok değișik durum oyun teo- 
risi ile analiz edilebilir. Tüm bu durumların ortak noktası, oyuncuların stratejilerinin (kararlarının) neticesinin diğer oyuncularınkine bağımlı olmasıdır.

Bu yüzden oyun teorisi, rekabetin yer aldığı ekonomik piyasalarda karar alınmasında önemli ipuçları sağlar.

Oyun teorisinin en önemli özelliği sezgisel anlayıșların sayısal modellere dönüștürülebilmesidir (Davis, 1983, s. xv). Ayrıca bir amaç için tasarlanmıș bir model, bambașka bir durum için de kullanılabilir. Birbirine hiç benzemediği düșünülen iki problem aynı metot kullanılarak çözülebilir.

Bununla birlikte, insanların birbirleriyle etkileșim içinde oldukları ortamların incelenmesi neticesinde, zaman zaman insan davranıșlarının oyun teorisi kuramlarından sapabildiği, insanların yaptıkları seçimlerin tamamen rasyonel olmadığı gözlemlenmiștir. Bu gözlemler neticesinde analitik oyun teorisine, duygu, hata, sınırlı öngörü, diğer insanların idraki (anlama yeteneği) hakkındaki șüphe ve öğrenme gibi etmenler eklenerek, evrimsel (davranıșsal) oyun teorisi geliștirilmiștir (Camerer, 2003, s. 3).

Amerikalı matematikçi John Forbes Nash 1950 yılında ișbirliksiz oyunlar üzerine yazdığı 28 sayfalık doktora teziyle oyun teorisi alanında yeni bir çığır açmıștır. Bu tezinde Nash, oyun teorisinde bir dönüm noktası olan "Nash dengesi" kavramını ortaya atmıștır. 1950-1953 yılları arasında toplam dört makale yazan Nash, bu çalıșmaları ile oyun teorisinin gelișimine büyük katkı sağlamıș ve daha sonra 1994 yılında, iki diğer oyun teoristi Reinhard Selten ve John Harsanyi ile beraber ekonomi dalında Nobel ödülünü kazanmıștır.

Nash dengesinin bulunması ve akabinde ișbirliksiz oyun teorisindeki gelișmeler, uygulamalı iktisat çalıșmalarının alanını genișletti. Ekonomi, toplum kurumlarında rasyonel rekabetçi davranıșın incelenmesi olarak yeniden tanımlandı. Böylece ișbirliksiz oyun teorisini, fiyat teorisinin yanında temel analiz metodolojisi olarak kabul eden ekonomik analiz, bu bilime ismini veren antik Yunan filozoflarının vizyonuna tekrar kavuștu (Myerson, 1999). 


\section{3. Ültimatom Oyunu}

Ültimatom oyunu deneysel ekonomi ile ilgilenen bilim adamları tarafından üzerinde çok çalıșılmıș basit bir pazarlık oyunudur. Oyun, belli bir paranın iki oyuncu tarafından nasıl paylașılacağı üzerine kurgulanmıștır. Birinci oyuncu, miktarın nasıl bölüșüleceğini ikinci oyuncuya teklif eder. İkinci oyuncu bu teklifi ya kabul ya da reddeder. Ikinci oyuncu teklifi kabul ederse, para birinci oyuncunun teklif ettiği oranlarda paylașılır. Eğer ikinci oyuncu teklifi reddederse her iki oyuncu da hiçbir șey alamaz. Mukabele olmaması için oyun aynı oyuncular arasında sadece bir kere oynanır. Oyunculara bu oyun gerçek para ile oynatılır ve oyuncular birbirlerinin kim olduğunu bilmezler.

Örneğin, paylașlacak miktar 100 TL ve birinci oyuncu ikinci oyuncuya "Ben 70 lira alayım, sana 30 lira vereyim" șeklinde bir teklif yapmıș olsun. Eğer ikinci oyuncu bu teklifi kabul ederse, birinci oyuncu $70 \mathrm{TL}$, ikinci oyuncu $30 \mathrm{TL}$ alır. Eğer ikinci oyuncu bu teklifi kabul etmez ise, her iki oyuncu da sıfır TL alır.

Düğünlerde davetlilerin fotoğraflarının çekilmesi ülkemizde çok rastlanan bir ültimatom oyunu örneğidir. Nikah akdinden sonra gelinle damat masaları gezer ve davetlilerle fotoğraf çektirirler. Daha sonra fotoğrafçı, davetlilere çektiği fotoğrafları sabit bir fiyattan teklif eder. Davetli ya fotoğrafı satın alır (teklifi kabul eder) ya da satın almaz (reddeder). Teklif kabul edilirse davetli fotoğrafa, fotoğrafçı da paraya sahip olur. Teklif reddedilirse her ikisi de hiçbir șeye sahip olamaz.

Analitik (rasyonel seçimli) oyun teorisi oyuncuların menfaatçi olduğunu ve kendi kazançlarını maksimize etmek istediklerini kabul eder. Eğer oyuncular sadece kendi kazançlarını maksimize etmekle ilgileniyorsa, ikinci oyuncu kendisine teklif edilen miktarı, ne kadar küçük olursa olsun kabul edecektir; çünkü alternatifi hiçbir șey elde etmemektir. İkinci oyuncunun bu șekilde akıl yürüteceğini tahmin eden birinci oyuncu da, kendi kazancını maksimize etmek için ikinci oyuncuya en düșük rakamı teklif edecektir. Örneğin paylașilacak miktar $100 \mathrm{TL}$ ise (100 adet 1 TL den olușan), analitik (rasyonel seçimli) oyun teorisine göre rasyonel bir strateji, birinci oyuncunun ikinci oyuncuya 1 TL teklif edip, 99 TL'yi kendi- 
sine ayırmasıdır. Illk hamleyi yaptığından dolayı bu oyunda birinci oyuncu pazarlık gücüne sahiptir ve menfaatçi olduğundan kendi kazancını maksimize etmeye çalıșacaktır. Aynı șekilde menfaatçi (rasyonel) bir ikinci oyuncu da, ne koparabilirse ona razı olacaktır. Ültimatom oyunu için yukarıdaki netice alt-oyun mükemmel denge noktasıdır.

Bir alt-oyun, kendi bașına bir oyun olarak düșünülebilen ve ana oyunun parçası olan bir oyundur. Geriye doğru çıkarım (tümevarım) metoduyla alt oyun için bulunan denge "alt-oyun mükemmel dengesi" olarak adlandırılır (Dixit, Skeath, \& Reiley, 2009).

Yukarıdaki gibi 1-99 paylașımı birçok kiși tarafından adaletsiz olarak algılanır. Bu yüzden ültimatom oyunu bireyin adalet uğruna bir bedel ödeyip ödemeyeceğini gösteren güzel bir örnektir. Yukarıdaki düğün örneğinde, eğer davetliler fotoğrafçının adil olmayan bir fiyat istediğini düșünürlerse fotoğrafı satın almaz. Böylece hem fotoğrafçı kaybeder (para kazanamaz) hem de davetliler kaybeder (güzel bir anı fotoğrafına sahip olamazlar).

Ekonominin dinamikleri içinde gerçekleșen birçok olay ültimatom oyunu mantığı içerisinde irdelenebilir. Bu konuda literatüre girmiș örneklerden biri Reykjavik bankasının, Reykjavik Savings Bank (RSB), özelleștirme sürecidir (Baldursson, 2006). İzlanda'da özelleștirme politikaları çerçevesinde RSB'nin özel bir bankaya satılacağının duyulmasından sonra kamuoyunda aleyhte bir hava olușmuș ve kamuoyunun baskısına dayanamayan Izlanda Parlamentosu, oybirliği ile kabul ettiği bir kanunla, satıșı askıya almıștır.

Baldursson (2006), bu vakayı bir ültimatom oyunu olarak görmüștür. Özel banka teklifini yapmıș, cevap veren oyuncu durumunda olan halk teklif edilen șartlarla yapılacak özelleștirmeyi adaletsiz bir teklif olarak algılamıș ve reddetmiștir. Sonuçta kamuoyu baskısı neticesinde özelleștirme askıya alınmıștır. RSB'nin özelleștirilmesi her ne kadar İzlanda finans sektörünü daha verimli hale getirecek ve halkın bundan maddi kazancı olacak olsa da, özelleștirme șartlarının RSB'yi satın alan özel bankaya haksız kazanç sağladığına inanan halk, kendi maddi menfaati pahasına, satıș ișlemine muhalefet etmiștir. 


\section{Adalet Kavramı ve Ekonomik Karar Alma}

Adalet algısı insandaki en temel değerlerden biridir ve hatta bașka canlılarda da olabileceği düșünülmüștür. Örneğin kahverengi kapuçin maymunları, aynı görevi yerine getiren diğer maymunlardan daha düșük bir ödül aldıkları zaman kızgınlık ve hüsran belirtileri gösterir. Bilim insanları bu șekilde haksızlığa uğratılan maymunların küstüğünü, bașka görev yapmadığını hatta yiyeceklerini araștırmacılara geri fırlattığını gözlemlemiștir (Fisher, 2008 , s. 33). Fisher'ın bu iddiasına karșın, maymunlarda adalet kavramının olmadığını gösteren çalıșmalar da vardır ( Jensen, Call, \& Tomasello, 2007).

Sosyologlar da adalet kavramı üzerine teoriler geliștirmiș ve bu kavramı çeșitli açıdan analiz etmiștir. Metin (2014), Thomas Hobbes'in Leviathan isimli eserinden yola çıarak, oyun teorisi perspektifinden analiz ettiği sosyal sözleșme kuramında așağıdaki gibi bir adalet yorumu ortaya koyar;

"Karșılıklı yarar yaklașımının özü, bașkalarına karșı hiçbir doğal sorumluluğumuz olmadığı düșüncesidir. Karșılıklı yarar kuramcıları, yaptığım iș ancak benim bir isteğimi karșılayacaksa bir șey yapma gerekçem olduğunu savunur. Ahlaki eylemler, benim isteğimin tatminini artırmıyorsa, bunları yapmak için hiçbir gerekçem yoktur. Bu yüzden adalet de kișinin çıkarına olduğu takdirde adil davranıș ediminin bir gerekçesi olabilecektir. Insanların adil davranması, adaleti bir değer olarak kabul ettikleri için değil, "karșı konulamayacak bir güce" sahip olmadıklarındandır. Güçsüz olanı koruma görevini görmezden gelen, savunmasızlara karșı hiçbir yükümlülüğümüz bulunmadığını öne süren bu yaklașım, "kișisel farklılıkların yeterince büyük olduğu" noktalarda sömürüye göz yumacaktır." (Metin, 2014)

Öte yandan, insanların sadece kendi menfaatleri doğrultusunda değil, ama bașkalarına da faydalı olmak için uğraștığı yadsınamaz bir gerçektir. Fakat bu bașkalarına faydalı olabilmek arzusu, bașkalarının kendisine nasıl davrandığı ile de doğru orantılıdır. Eğer biri size iyi davranırsa, adalet kavramı ona iyi davranmanızı ister. Eğer biri size zarar verirse, adalet kavramının müsaadesi ve karșilıklılık mefhumunun isteği ile siz de ona zarar 
verirsiniz. Bu davranıș modelinin ekonomik boyutları da mevcuttur; iyi çalıșan bir ișçinin maașını patronu yükseltmek ister, insanlar faydalı olduğuna inandıkları vakıflara bağıș yapar, müșteriler ihtiyaçları olsa dahi așırı pahalı satıș yapan firmadan alıșveriș yapmak istemez vs. (Rabin, 1993).

Adalet algısının ekonomik teoriye eklemlenmesi ültimatom oyunu ile yapılan deneyler sayesinde olmuștur (Roth, 1995). Ültimatom oyunu ile yapılan ilk deneylerde (Güth, Schmittberger, \& Schwarze, 1982) oyuncuların adil bir paylașımı tercih ettikleri (yarıya yakın bir miktarı karșı oyuncuya teklif etmek) ve adaletsiz bir teklif karșısında (teklif edilen rakam paylașılacak miktarın \%20 'sinden düșükse) teklifi reddederek, kendi kayıpları pahasına, diğer oyuncuyu cezalandırmakła tereddüt etmedikleri gözlenmiștir.

Daha sonraki yıllarda yapılan benzer çalıșmalar, Güth vd.'nin bulgularını desteklemekle beraber, oyuncuların rasyonel davranıștan saparak (maddi kazancı maksimize etme), alt-oyun mükemmel dengesi tahminine uygun hareket etmeme sebebinin sadece tek yönlü bir adalet algısı ile açıklanamayacağını ortaya koymuștur (Forsythe, Horowitz, Savin, \& Sefton, 1994). Forsythe vd. göre bașka bir sebep farklı tipte oyuncuların varlığı olabilir. Bazı oyuncular için adalet olgusu mühimken, bazı oyuncular sadece maddi güdülerle hareket edebilir. Aynı șekilde karșılıklılık olgusu da, bazı oyuncular için așırı düșük teklifleri reddetmede geçerli bir sebep olabilir.

Bireyin adalet algısının ekonomik davranıșa ne kadar yansıyacağını ölçmek ve bu algının bileșenlerini tanımlayabilmek için ültimatom oyunu kullanılarak pek çok deney yapılmıștır. Acaba ikinci oyuncu adaletsiz olduğuna inandığı bir teklifi reddederek maddi kayba uğramayı göze alacak mıdır? Acaba birinci oyuncu, ikinci oyuncunun adaletsiz teklifleri reddedeceğini düșünüp adil bir teklif yapacak mıdır? Paylașılacak miktarın oyuncuların teklifleri üzerinde bir etkisi var mıdır? Oyuncuların davranıșları sadece adalet algısı ile mi güdülenmiștir yoksa bașka etmenler de var mıdır? Adalet algısı kișiden kișiye veya toplumdan topluma farklılık gösterir mi? Adalet algısının bileșenleri nelerdir? 
Ültimatom oyunu kullanılarak yapılan deneylerde, teklif eden oyuncunun teklif ettiği miktarı etkileyen ve cevap veren oyuncunun bu miktarı ret/kabul etmesini belirleyen birçok unsur bulunmuștur. Bu unsurların en önemlileri așağıdakilerdir;

\subsection{Paylașım Miktarı}

Oyuncuların davranıșlarının paylașılacak kazanç miktarından etkilenip etkilenmediğini gözlemlemek için değișik ülkelerde yapılan ültimatom oyunu deneyleri hep benzer sonuçlar vermiștir. Birçok ülkede 10 USD üzerinden yapılan deneylerde, birinci oyuncunun teklifi 4 USD ile 5 USD arasında yoğunlașmıștır. 2 USD ve altı tekliflerin yarısı reddedilmiștir. Ikinci oyuncular, yarının çok altında olan tekliflerin adaletsiz olduğunu düșünmekte ve böyle bir teklif yaptığı için, kendi kayıpları pahasına, birinci oyuncuyu cezalandırmaktadır. Paylașılacak rakam bir miktar artsa dahi, birinci oyuncular bu davranıș șeklini fazla değiștirmemektedir.

Camerer (2003, s.10) Hoffman, McCabe, ve Smith'in iki ayrı paylașım miktarı (10 USD ve 100 USD) kullanarak yaptığı çalıșmasının bulgularını (Hoffman, McCabe, \& Vernon, On Expectations and the Monetary Stakes in Ultimatum Games, 1996) așağıdaki gibi özetlemiștir; 
Șekil 1: Düșük Miktar (10 USD) ve Yüksek Miktar (100 USD) için Ültimatom Oyunu Neticeleri

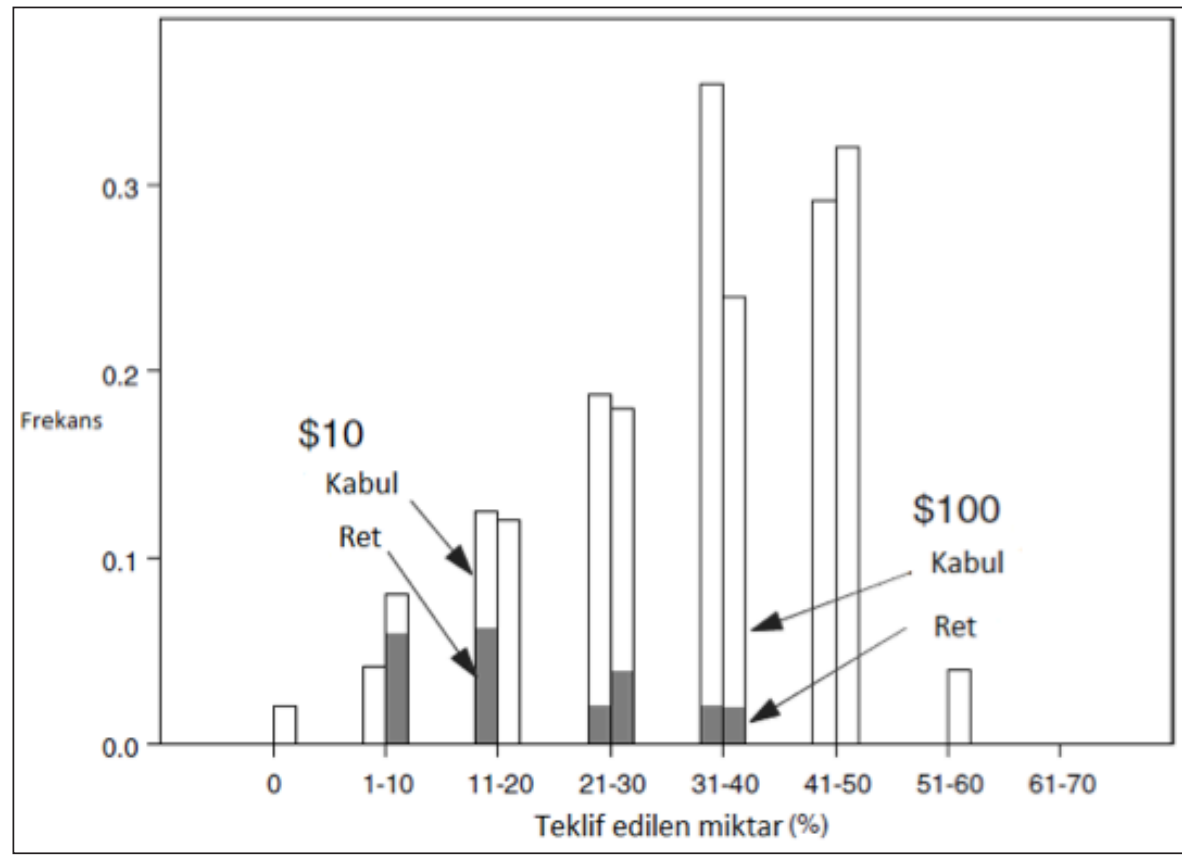

Kaynak: Camerer, C. F. (2003). Behavioral Game Theory. Princeton University Press.

$X$ ekseni, birinci oyuncu tarafından teklif edilen miktarı, $Y$ ekseni ise tekliflerin nisbi frekansını göstermektedir. Her frekans çubuğunun koyu kısmı reddedilen teklif sayısıdır. Șekil 1 de de görüldüğü gibi tekliflerin çoğu yarı miktar civarındadır ve çok düșük teklifler genelde reddedilmektedir.

Kazanç miktarları önemli ölçüde artığı zaman neticenin teklif eden açısından çok fazla değișmediği, cevaplayan açısından ise farklılık gösterdiği bașka çalıșmalarda da ortaya çıkmıștır (List \& Cherry, 2000); 
Tablo1: Teklif ve Ret Adetleri (USD 20 ve USD 400 için)

\begin{tabular}{|lccccc}
\hline & \multicolumn{2}{c}{ Düşük miktarlar } & & \multicolumn{2}{c}{ Yüksek miktarlar } \\
\cline { 2 - 3 } \cline { 5 - 6 } Teklif aralığı (\%) & \% Teklif edilen & \% Reddedilen & & \% Teklif edilen & \% Reddedilen \\
\hline$>50$ & $8.6(25)$ & $12.0(3)$ & & $4.4(12)$ & $0(0)$ \\
$=50$ & $14.8(43)$ & $4.7(2)$ & & $15.2(41)$ & $4.9(2)$ \\
$45.0-49.5$ & $9.0(26)$ & $23.1(6)$ & & $7.0(19)$ & $10.5(2)$ \\
$40.0-44.5$ & $12.1(35)$ & $14.3(5)$ & & $11.9(32)$ & $9.4(3)$ \\
$35.0-39.5$ & $7.9(23)$ & $30.4(7)$ & & $8.5(23)$ & $17.4(4)$ \\
$30.0-34.5$ & $9.3(27)$ & $29.6(8)$ & & $8.5(23)$ & $17.4(4)$ \\
$25.0-29.5$ & $10.3(30)$ & $43.3(13)$ & & $17.0(46)$ & $28.3(13)$ \\
$<25.0$ & $27.9(81)$ & $71.6(58)$ & & $27.4(74)$ & $55.4(41)$ \\
Tüm teklifler & $100.0(290)$ & $35.2(102)$ & & $100.0(270)$ & $25.6(69)$ \\
Teklif $<50.0$ & $76.6(222)$ & $43.7(97)$ & & $80.4(217)$ & $30.9(67)$ \\
Ortalama & 33.78 & - & 31.89 & - \\
\hline Toplam denek sayısı düşük miktarlar için 290, yüksek miktarlar için 270' tir. & \\
\hline Parantez içindeki rakamlar, o aralıktaki teklif ve ret adetleridir. & \\
\hline
\end{tabular}

Kaynak: List, J. A., \& Cherry, T. L. (2000, Haziran). Learning to Accept in Ultimatum Games: Evidence from an Experimental Design that Generates Low Offers. Experimental Economics, s. 11-29.

Sonuçlar açık olarak oyuncuların adaletle muamele edilmek istediklerini ortaya koymaktadır. Bu davranıș olumsuz mütekabiliyet / karșilıklılık (negative reciprocity) ilkesi ile de açıklanabilir (Camerer, 2003, s. 10); birey adaletsiz muameleye aynı șekilde karșilık verir. Birey kendisine adaletsiz davranarak zarar veren kișiye, kendi de zarara uğramak pahasına (o kiși daha fazla zarara uğradığı müddetçe) zarar verir. Gazetelerin üçüncü sayfalarında sık sık rastladığımız yüksek nafakalı boșanma haberleri, namus cinayetleri, anlașılabilecekken uzatılan mahkemeler olumsuz mütekabiliyet örnekleridir.

\subsection{Kültürel Farklılık}

Ültimatom oyununun farklı ülkelerde farklı netice verip vermeyeceğini görmek için birçok deney yapılmıștır (Oosterbeek, Sloof, \& van de Kuilen, 2004). Gözlemlenen değișikliklerin genelde 
kültürel farklılıktan kaynaklandığı kabul edilmiștir. Oosterbeek vd. (2004) 25 ayrı ülkeden 37 deneyi karșılaștırdığı çalıșmasında, teklif eden oyuncuların davranıșında anlamlı bir farklılık olmadığını gözlemlemiștir. Mamafih, cevaplayan oyuncuların davranıșları farklılık göstermiștir. Asyalı cevaplayan oyuncuların reddetme oranları ABD'li oyuncularınkinden yüksektir. Amerika'nın bałı tarafındaki oyuncuların ret oranları da, Amerika'nın doğu tarafındakilerden düșüktür. Ayrıca ülkelerin rekabetçilik endeksindeki yerinin, kiși bașına düșen milli gelir miktarının ve gelir dağılımındaki eșitsizliğin oyuncuların davranıșını etkilemediği anlașılmıștır. Fakat paylașilacak miktar hem teklif eden hem de cevaplayan oyuncunun davranıșını etkilemektedir. Bu netice, yapılan bazı çalıșmalarla örtüșmekle beraber, bazılarıyla da örtüșmemektedir.

\section{Tablo 2: Ülke Sonuçları}

$\begin{array}{lccc}\text { Ülke } & \text { Deney Adedi } & \text { Teklif Ortalaması } & \text { Ret Ortalaması } \\ \text { Avusturya } & 1 & 39,21 & 16,10 \\ \text { Bolivya } & 1 & 37,00 & 0,00 \\ \text { Șili } & 1 & 34,00 & 6,70 \\ \text { Ekvador } & 2 & 34,50 & 7,50 \\ \text { Fransa } & 3 & 40,24 & 30,78 \\ \text { Almanya } & 1 & 36,70 & 9,52 \\ \text { Honduras } & 1 & 45,70 & 23,05 \\ \text { Endonezya } & 4 & 46,63 & 14,63 \\ \text { İsrail } & 5 & 41,71 & 17,73 \\ \text { Japonya } & 3 & 44,73 & 19,27 \\ \text { Yugoslarya } & 1 & 44,33 & 26,67 \\ \text { Kenya } & 1 & 44,00 & 4,00 \\ \text { Moğolistan } & 2 & 35,50 & 5,00 \\ \text { Hollanda } & 2 & 42,25 & 9,24 \\ \text { Papua Yeni Gine } & 2 & 40,50 & 33,50 \\ \text { Paraguay } & 1 & 51,00 & 0,00 \\ \text { Peru } & 1 & 26,00 & 4,80 \\ \text { Romanya } & 2 & 36,95 & 23,50\end{array}$




$\begin{array}{lccc}\text { Slovakya } & 3 & 43,17 & 12,67 \\ \text { İspanya } & 1 & 26,66 & 29,17 \\ \text { İsveç } & 1 & 35,23 & 18,18 \\ \text { Tanzanya } & 4 & 37,50 & 19,25 \\ \text { Birleșik Krallık } & 2 & 34,33 & 23,38 \\ \text { ABD-Doğu } & 22 & 40,54 & 17,15 \\ \text { ABD-Batı } & 6 & 42,64 & 9,41 \\ \text { Zimbabve } & 2 & 43,00 & 8,50\end{array}$

Kaynak: Oosterbeek, H., Sloof, R., \& van de Kuilen, G. (2004). Cultural Differences in Ultimatum Game Experiments: Evidence from a Meta-Analysis. Experimental Economics, 7, s. 171-188.

Adalet algısının kültürden kültüre değișmesi, ültimatom oyununun kültürel farklılık gösteren toplumlarda, batı toplumlarına nazaran daha değișik neticeler vermesine yol açmıștır. Peru, Amazon yerlileri arasında yapılan bir ültimatom oyunu çalıșması, kültürel farklılıkların temel ekonomik davranıș șekillerini kökten etkilediğini göstermiștir (Henrich, 1998). Batı dünyasında \%50 civarında olan teklif edilen paylașım ortalaması Machiguenga yerlileri arasında \%26'ya düșmüștür. Batı dünyasında \%20'nin altında olan teklifler reddedilirken, Machiguenga yerlileri \%20'nin altındaki tekliflerin neredeyse hepsini kabul etmișlerdir.

Deney sonrası yapılan görüșmelerde Machiguenga yerlileri, teklif edenin ne kadar kazandığına hiç bakmadan, kendilerine teklif edilen her rakamı kabul edeceklerini ve teklif edenin kendilerini kandırdığını düșünmediklerini, kendilerinin teklif edilen tarafta olmasını ise sadece șanssızlık olarak algıladıklarını belirtmișlerdir. Batı dünyasında ise bu deneye katılanlar, ortalama \%20'nin alında olan teklifleri adaletli bulmadıklarından reddedeceklerini söylemiștir.

$\% 50$ teklif eden az sayıda Machiguenga bu teklifi adaletli olduğu için yaptığını belirtmiștir. Kontrol grubunda (Los Angeles) $\% 50$ teklif eden batılı oyuncular ise bu teklifi, reddedilmekten korktukları için yaptıklarını belirtmișlerdir. 


\subsection{Beklenti, Karșilıklılık ve Niyet}

Ültimatom oyunundaki eșite yakın tekliflerin adalet kaygısından değil, beklentiden, mesela kıskançlık korkusundan kaynaklandığını savunan bağımsız çalıșmalar da vardır (Kirchsteiger, 1994). Kirchsteiger'e göre yarıya yakın bir paylașım teklif eden oyuncuların kaygısı adil olmak değil, kıskanç oyuncular tarafından reddedilme korkusudur.

Ültimatom oyunu üzerine yapılan çalıșmaların bir kısmı adalet kaygısından ziyade, oyuncuların beklentilerinin neticeyi etkilediğini göstermiștir (Hoffman E., McCabe, Shachat, \& Vernon, 1994). Adalet algısından kaynaklandığı düșünülen bir davranıș aslında bașkalarının ne düșündüğünü önemsemekten (sosyal endișe) ve bașkalarınca iyi algılanmak arzusundan kaynaklanabilir. Diğer bir deyișle oyuncular șimdiki bir masraf karșılığında gelecekte kazanç elde etmeyi ummaktadır. Böylece oyuncu nihai toplamda bir getiri elde etmiș olur. Hoffman vd.'ye (1994) göre, dürüstlük, paylașma gibi sosyal özellikler ancak birbirini tanıyan ve tekrar karșılașacak olan insanlar arasında bir kazanç sağlar. Oyuncuların tek bir kez karșılaștıkları, tekrar etmeyen oyunlarda, kișiler ilk elden kendi maddi kazançlarını maksimize etmeye çalıșır.

Hoffman vd. (1994) tarafından geliștirilen beklenti hipotezini (paylașımı teklif eden oyuncu, teklifini diğer oyuncunun vereceğini umduğu cevaba göre ayarlar ve toplumun onayını bekler) destekleyen ve geliștiren çalıșmalar, eșite yakın tekliflerin sadece adalet olgusu ile açıklanamayacağını göstermiștir (Suleiman, 1996). Böylece ültimatom oyununun rasyonel netice vermeme sebebi iki temel teoriyle; adalet teorisi ve beklenti teorisiyle açıklanmaya bașlanmıștır.

Beklenti teorisinde güven kavramının yerini araștıran çalışmalar ilgi çekici bulgular ortaya koymuștur (Cox, 2004). Güven, bir oyuncunun diğer oyuncunun davranıșı hakkındaki kanaatidir. Güven kaynaklı bir davranıș, karșı taraf ișbirliği yaptığı takdirde (beklentiye uygun davrandığı takdirde) karșılıklı kazanç, uygunsuz davrandığı takdirde ise kayıp getirir. Cox (2004), çalıșmasında üç ayaklı bir oyun kurarak güven, karșılıklılık (mütekabiliyet) ve adalet (maddi getiriyi göz önüne almayan ve diğer oyuncudan 
bağımsız, eșitlik veya fedakarlık arzusu kaynaklı olgu) etmenlerini ayrı ayrı ölçmüștür. Pozitif karșılıklılık ve adalet kavramlarını karıștırmamak gerekir. Pozitif karșılıklılık diğer oyuncunun cömertliğinden kaynaklanan cömert bir davranıștır, dolayısı ile diğer oyuncuya bağlıdır. Adalet ise karșıdaki oyuncunun tutumundan bağımsız cömert bir davranıștır.

Cox'un (2004) bulgularına göre kișinin adaletli davranma arzusu diğer oyuncunun algılanan niyetine bağlıdır. Ayrıca karșıdaki oyuncunun adalet ve karșılıkılık algısı temelli davranıșları hakkındaki kanaat (beklenti) de kișinin kararını etkilemektedir.

Adaleti önemseyen insanlar adil veya adil olmayan niyetlere göre mi, yoksa adil veya adil olmayan neticelere göre mi davranıșını düzenler? Niyetin hiçbir öneminin olmadığını savunan modeller olduğu gibi, niyetin davranıșlar üzerinde önemli bir etkisi olduğunu savunan modeller de vardır (Falk, Fehr, \& Fischbacher, 2008). Bu sorunun cevabı ekonomik teori açısından önemlidir çünkü klasik fayda kuramı (utility theory) ekonomik davranıșın faydasının sadece sonucuna bağlı olduğunu, niyetin herhangi bir önemi olmadığını savunur. Fakat yukarıda da tartıșıldığı gibi, ekonomik kararların nasıl alındığının anlașılabilmesi açısından, diğer oyuncunun niyetinin karar mekanizmasını nasıl etkilediğinin bilinmesi önemlidir.

Falk vd. (2008), hem negatif hem de pozitif karșılıklılık (mütekabiliyet) davranıșlarında, adalet niyetinin önemli olduğu sonucuna ulașmıștır. İnsanlar bir hareketin adil olup olmadığına karar verirken sadece hareketin neticesine değil, davranıșı gösteren kișinin niyetine de bakar. Bu sonuç, bir hareketin faydasını sadece neticesine göre ölçen klasik ekonomik teorisinin varsayımlarıyla ters düșmektedir.

\subsection{Davranıș Modelleri}

İnsanların kendi maddi kazançlarının haricindeki șeylere adalet perspektifinden ne derece önem verdiği ve hangi davranıș modellerine (kurallarına) göre karar verdiği bilim insanları tarafindan muhtelif sosyal tercih modellemeleri vasitasıyla analiz edilmiștir. 
Temelde iki tip sosyal tercih modelinden söz edebiliriz. Birinci tip modellerde insanlar kazancın (netice / payoff) hangi oranda dağıtıldığı ile ilgilenir. Bu tip modellerde oyuncu için önemli olan hem kendi kazancı hem de kazancının diğer oyuncuların kazancına oranıdır. İkinci tip modellerde ise insanlar diğer oyuncuların niyetlerine önem verir ve mütekabiliyet (karșılık verme) duygusuyla hareket eder. Bu modellemeye göre, oyuncu maddi kazançtan fedakarlık ederek, adil yaklașımı ödüllendirmek, haksız yaklașı$\mathrm{mı}$ ise cezalandırmak isteyebilir. Fakat yapılan çalıșmalar her iki modelin de tek bașına insan davranıșını açıklayamadığı, her iki modelin özelliklerini bir araya getiren bir üçüncü modele ihtiyaç olduğunu göstermiștir. (Bereby-Meyer \& Niederle, 2005).

Bu çerçevede ekonomik alandaki tartıșmaların bir tanesi de, gelir dağııımındaki adaletin, yetenek ve çalıșmayı ne derecede göz önüne aldığı ile ilgilidir. Standart ültimatom oyununda paylașılacak miktar herhangi bir çalıșmanın neticesinde kazanılmadığından, 50-50 bir paylașım adil olarak algılanır. Fakat ișin içine üretim ve üretimi etkileyen faktörler girdiğinde, acaba yine 50-50 paylașım adil olarak mı algılanacaktır? 2005 yılında yapılan bir çalıșma değișik adalet anlayıșlarını ve bu anlayıșlara kișilerin verdiği önemi analiz etmiștir (Cappelen, Hole, Sorensen, \& Tungodden, 2006).

Katı eșitlikçi anlayıșa göre, birey yetenek ve çalıșmasından sorumlu tutulamaz. Dolayısıyla her șartta eșit bir bölüșüm adil bir bölüșümdür. Liberter yaklașım ise kișinin yetenek ve çalıșmasından sorumlu olduğuna inanır. Dolayısıyla adil bir paylașım kișinin ürettiği kadar almasıdır. Liberal eșitlikçiler ise kișinin çalıșmasından sorumlu olduğunu ama yeteneğinin kendi kontrolünde olmadığını savunur. Bu akıma göre adil bir dağııım, yetenek farklııklarını eșitlemeli ama çalıșma farklılıklarını göz önüne almalıdır.

Cappelen vd. (2006) bulgularına göre insanların çoğu yetenek ve çalıșmanın ayrı ayrı değerlendirilmesi gerektiğine inanır. Bu çalıșmada katılımcıların çoğu liberal eșitlikçi doktrinden yana olsa da, diğer yaklașımlara inanan oyuncular da olmuștur.

Bu yönde yapılan çalıșmalar iki farklı bilim dalını, psikoloji ve ekonomiyi oyun teorisinin șemsiyesi altında bir araya getirmiș- 
tir. Yukarıda da görüldüğü gibi, birçok insan davranıșının temelinde kișisel çıkar kaygısı yatar. Kișisel çıkar kaygısı ile yapılan hareketler iki tiptir; saf bencil (pure selfishness) davranıș ve kendine hizmet eden (self serving) davranıș (Ubeda, 2014).

Saf bencil davranıș, kișinin maddi çıkarını maksimize etmesi üzerine odaklanmıștır ve rasyonel seçimli oyun teorisinin temel kabulüdür. Saf bencil davranıs gösteren oyuncular karar alırken diğer oyuncuların çıkarları ile ilgilenmez, tek odak noktaları kendi maddi çıkarlarıdır.

Kendine hizmet eden davranıș biçiminde ise kiși kendi maddi çıkarının yanında, diğerlerinin çıkarları ile de ilgilidir. Oyuncunun beklentisi, diğerlerinin çıkarının kendi çıkarına hizmet etmesidir. Bu yüzden bu șekilde davranan bir oyuncu karar verirken birden fazla etmeni göz önüne almak zorundadır.

Ubeda (2014), adil davranıș biçimlerinin tutarlılığı üzerinde yaptığı çalıșmada, kișilerin farklı adil davranıș kuralları olduğunu belirlemiștir. Saf bencil davranıș gösteren oyuncular bu davranıșlarında tutarlı olurken, kendine hizmet eden davranıșı gösteren oyuncularda zaman zaman tutarsızlık gözlemlenmiștir. Bu çerçevede saf bencil davranıș karar süresinin, kendine hizmet eden davranıș karar süresinden daha kısa olduğu belirlenmiștir. Bu çalıșmanın önemli bir bulgusu da, oyuncuların duruma göre, farklı adil davranıș yaklașımlarını benimsedikleridir.

Tablo 3: Aynı Kuralı Tekrarlayan Oyuncuların Adedi ve Yüzdesi

\begin{tabular}{|c|c|c|c|c|}
\hline & 20 Kere (her seferde) & 19 Kere & 18 Kere & 17 Kere (seferlerin $\% 85^{\prime}$ inde) \\
\hline Katı eşitlikçi & $3(5 \%)$ & $4(6.6 \%)$ & $6(10 \%)$ & $7(11.6 \%)$ \\
\hline Liberal essitlikci & 0 & 0 & 0 & 0 \\
\hline Liberter & 0 & 0 & 0 & 0 \\
\hline Bencil & $18(30 \%)$ & $19(31.6 \%)$ & $20(33.3 \%)$ & $21(35 \%)$ \\
\hline Cömert & $1(1.7 \%)$ & $1(1.7 \%)$ & $1(1.7 \%)$ & $1(1.7 \%)$ \\
\hline
\end{tabular}

Kaynak: Ubeda, P. (2014). The consistency of fairness rules: An experimental study. Journal of Economic Psychology 41, s. 88-100.

Tablo 3 tutarlı olarak 17 seferden fazla aynı davranıșı gösteren oyuncuların adet ve yüzdelerini göstermektedir. Sadece bencil, katı eșitlikçi ve cömert davranıșlar tutarlı olarak tekrarlanmıștır. Hiçbir oyuncu liberal eșitlikçi ve liberter davranıș biçimlerini tutarlı olarak tekrarlamamıștır. Bu tablo bencil, katı eșitlikçi ve cömert 
davranıș sergileyen oyuncuların davranıșlarında tutarlı olduğunu ama liberal eșitlikçi ve liberter davranıș sergileyen oyuncuların her seferinde aynı tutumu göstermediğini ortaya koymaktadır.

Șekil 2: Oyuncuların Ortalama Yanıt Süresi

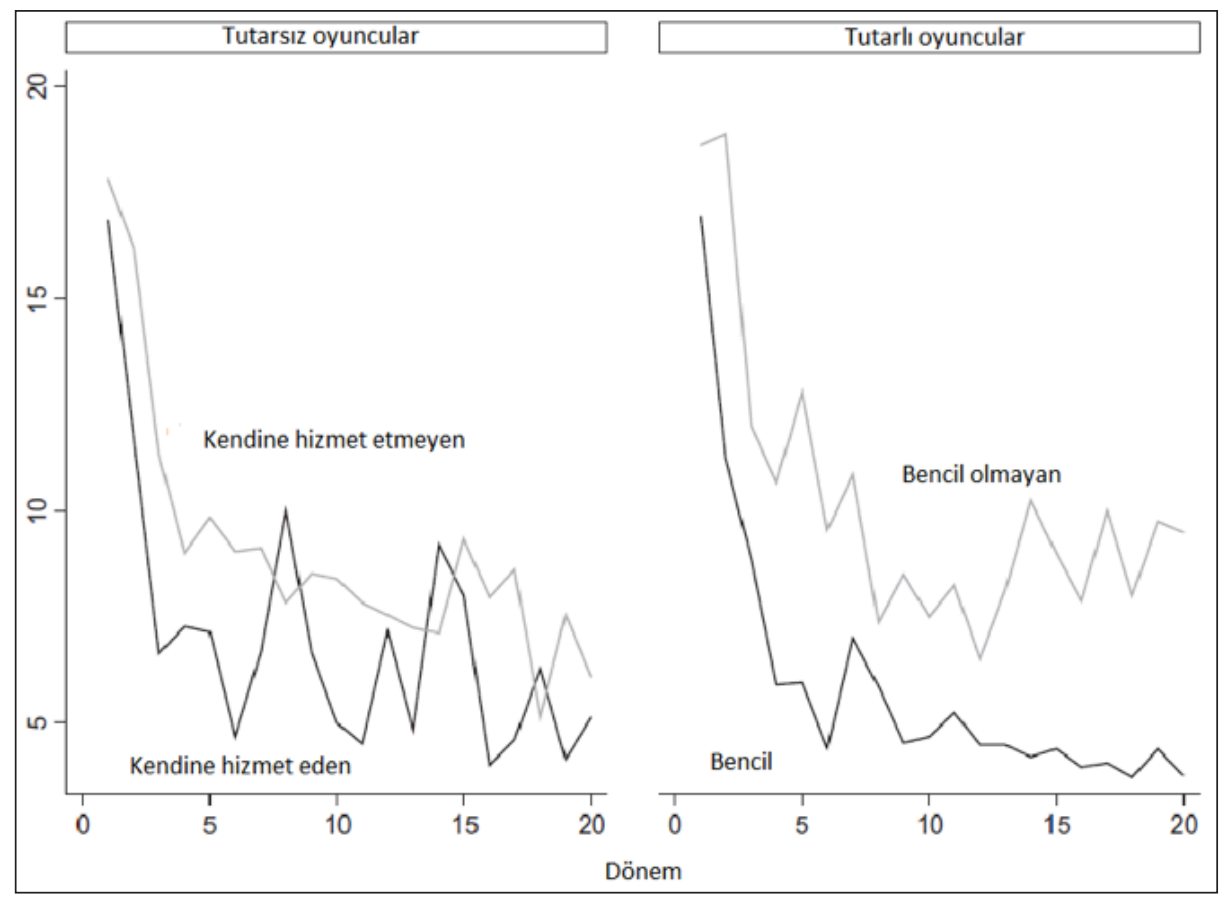

Kaynak: Ubeda, P. (2014). The consistency of fairness rules: An experimental study. Journal of Economic Psychology 41, s. 88-100.

Șekil 2 bencil davranıșların, oyuncular sadece maddi kazanca odaklı olduğundan, daha otomatik olduğunu, dolayısıyla karar sürelerinin daha kısa olduğunu göstermektedir. Kendine hizmet eden oyuncular kendi menfaatlerini öncelemekte ama toplum tarafından da iyi olarak görülmek istemektedir. Bu sebeple kendisi ile diğer oyuncu arasında çözmesi gereken bir menfaat çatıșması yoktur. En yavaș karar veren, kendine hizmet etmeyen oyuncular ise her seferinde değișik adalet yaklașımları (davranıș kuralları) arasında bocalamaktadır. 


\section{5. İdrak}

Adalet algısını psikolojik teoriler açısından inceleyen bilim insanlarının üzerinde çalıștıkları bașka bir konu da, insan idrakinin gelișimi ile adil davranıș arasında bir bağ olup olmadığıdır (Takagishi, Kameshima, Schug, Koizumi, \& Yamagishi, 2010). Toplum, sosyal normlara aykırı davrananları cezalandırarak, düzeni korumayı ve ișbirliğini artırmayı amaçlar. Bireyin aykırı davrandığı, diğer bireylerle ișbirliğine gitmediği zaman toplum tarafından cezalandırılacağını bilmesi onu ișbirlikçi ve adil davranmaya teșvik eder. Fakat bu teșvikin geçerli olabilmesi için kișinin diğer insanların sosyal tercihlerini bilmesi (anlaması), ve kendi davranıșlarına nasıl tepki vereceklerini kavraması lazımdır.

Bu teoriden yola çıkarak, Takagishi vd. (2010) idrak (anlayıș) gelișiminin adalet algısına etkisini ölçmek için okul öncesi çocuklar üzerinde șeker kullanarak bir çalıșma yapmıștır. Yapılan çalıșma anlayıș gelișiminin teklif eden oyuncunun adalet algısı üzerinde çok kuvvetli bir etkisi olduğunu göstermiș̦tir. İdrakleri tam gelișmemiș daha genç oyuncuların șeker paylașma teklifleri ağırlıklı olarak çok bencilken, yașları biraz daha büyük oyuncular daha adil teklifler yapabilmiștir. Diğer bir deyișle, yașı biraz daha büyük olan ve karșıdakinin çok adaletsiz bir teklife olumsuz cevap vereceğini idrak edebilen okul öncesi çocuklar, daha adil paylașım teklifleri yapmıșıır. Takagishi vd. (2010) bu sonucun bu konuda yapılan diğer çalıșmalarla uyum içinde olduğunu belirtmektedir.

Bu çerçevede insanların en yakın yașayan akrabaları olan ve insani manada bir anlayıșa (idrake) sahip olmayan șempanzelere ültimatom oyunu oynatan antropologlar, șempanzelerin adaletsiz teklif yaptıklarını ve adaletsiz teklifleri kabul ettiklerini gözlemlemiștir (Jensen, Call, \& Tomasello, 2007). Bu maymunların tam rasyonel oyuncu gibi davranmaları ve adalet kavramına duyarlı olmamaları, kendinden bașkasını düșünme ve haksız kazançtan kaçınma gibi sosyal yașamımızı düzenleyen temel değerlerin bizleri diğer canlılardan ayıran temel özelliklerden olduğunu bir kez daha göstermiștir. 


\subsection{Hayatta Kalma, Bilgi ve Fiziksel Güzellik}

Schotter vd. ültimatom oyunundaki adalet algısının hayatta kalma dürtüsü ile bağı olup olmadığını araștırmıștır (Schotter, Weiss, \& Zapater, 1996). Șirketler rekabet içindedir ve rekabet üstünlüklerini sürdürüp hayatta kalmak zorundadır. Ekonomik ortamda da oyuncular üzerinde hayatta kalma baskısı vardır. Kișisel menfaati önceleme haklı bir sebebe dayandığı sürece mazur görülebilir. Schotter vd. ültimatom oyununa varlığını sürdürme boyutu katarak deney yapmıș ve sınırlı da olsa bu boyutun davranıșlar üzerinde etkisi olduğunu gözlemlemiștir.

Oyuncuların ekonomik teoriye hakimiyetlerinin neticeyi etkileyip etkilemeyeceğini ölçmek için, ekonomi okuyan öğrencilere ve sanat okuyan öğrencilere ültimatom oyunu oynatılmıștır. Sonuçta ekonomik bilginin neticeyi etkilemediğini görülmüștür (Stanley \& Tran, 1998).

İlgi çekici bir çalıșma da, fiziksel güzelliğin ekonomik karar vermeye etkisinin olup olmadığını görmek için yapılmıșıı (Rosenthal, 2011 , s. 285). Birinci oyunculara, muhtemel ikinci oyuncuların fotoğrafları gösterilmiștir. Erkekler, çekici kadınlara çok yüksek teklifler yapmamakla beraber, kadınlar, yakıșıklı erkeklere oldukça yüksek (ortalamada toplam miktarın \%50'sinden fazla) tekliflerde bulunmuștur. Fiziksel güzelliğe sahip insanlar ortalamada \%10 daha yüksek teklif almıșlar, erkekler de kadınlardan ortalama \%15 daha fazla teklif almıșlardır.

Yukarıda açıklanan ültimatom deneylerinin sonuçları Tablo 4'de özetlenmiștir; 
Tablo 4: Oyuncuların Davranıșlarını Belirleyen Unsurlar

\begin{tabular}{|c|c|c|}
\hline Unsur & 1. Oyuncu & 2. Oyuncu \\
\hline Miktar & Sınırlı etkisi var. & $\begin{array}{l}\text { Paylașılacak miktar arttıkça ret } \\
\text { oranı azalıyor. }\end{array}$ \\
\hline \multirow[t]{2}{*}{ Kültür } & $\begin{array}{l}\text { Gelișmiș kültürlerde sınırlı } \\
\text { etkisi var. }\end{array}$ & Gelișmiș kültürlerde etkisi var. \\
\hline & \multicolumn{2}{|c|}{$\begin{array}{l}\text { Gelișmiș kültürlerle, gelișmemiș kültürler arasında büyük farklılık } \\
\text { var. }\end{array}$} \\
\hline Beklenti & Etkisi var. & Geçerli değil. \\
\hline Karșılıklılık & Etkisi var. & Etkisi var. \\
\hline Algılanan Niyet & Geçerli değil. & Etkisi var. \\
\hline Davranıș Modeli & Etkisi var. & Etkisi var. \\
\hline Idrak & Etkisi var. & Etkisi var. \\
\hline Rekabet & Sınırlı etkisi var. & Sınırlı etkisi var. \\
\hline Bilgi & Etkisi yok. & Etkisi yok. \\
\hline Fiziksel Güzellik & Etkisi var. & Geçerli değil. \\
\hline
\end{tabular}

\section{Sonuç}

Bireyin ekonomik karar alırken, klasik ekonomik teorinin varsaydığı gibi benmerkezci mi davrandığı, yoksa bașkasını da düșünüp düșünmediği, eğer düșünüyorsa hangi unsurların etkisinde kaldığı oyun teorisi yazınında farklı bașlıklar alıında ele alınmaktadır. Bu bașlıklardan biri olan ültimatom oyununun analiz edildiği çalıșmamızda, yapılan deneylerin neticeleri insanların ekonomik karar alırken kendi çıkarını gözettiği, ama bazı unsurların etkisi ile de, fedakarlık yapabileceği șeklinde ortaya çıkmıștır.

Ültimatom oyunu, teklif eden oyuncunun (birinci oyuncu), ikinci oyuncuya en düșük miktarı değil, ortalamada paylașılacak miktarın \%40'ını teklif etme eğiliminde olduğunu göstermiștir. Teklif edilen oyuncu (ikinci oyuncu) ise, ortalamada \%35-50 arası teklifleri kabul, \%20'den așağı teklifleri ret etme eğilimindedir.

Teklif miktarın ve teklif edilen miktarın kabul veya ret edilmesini etkileyen unsurlar, yapılan çalıșmalar neticesinde, așağıdaki 
bașlıklar altında belirlenmiștir. Bu unsurlar, daha genel bir yaklașımla, bireyin aldığı ekonomik kararlara yön veren unsurlardır;

- İnsanın umduğu maddi getirinin büyüklüğü kararını etkilemektedir. Kiși adaletle muamele görmek ister ve adaletsiz muameleye aynı șekilde karșılık verir. Birey kendisine adaletsiz davranarak zarar veren kișiye, kendi de zarara uğramak pahasına (o kiși daha fazla zarara uğradığı müddetçe) zarar verir. Ama bireyin kendi uğradığı zararın boyutu büyüdükçe, bireyin adaletsiz muameleyi kabullenme oranı yükselir. Örneğin paylașılacak miktar 100 milyon TL olsa ve birinci oyuncu ikinci oyuncuya sadece bir milyon TL teklif etse, birçok kiși, rakamın yüksekliğinden dolayı, bu teklifi kabul edecektir.

- Dünyanın değișik ülkelerinde yapılan ültimatom oyunu deneylerinde teklif edilen miktarlar ufak tefek sapmalar göstermiș, buna karșın reddedilen miktarlarda büyük farklilıklar ortaya çıkmıștır. Ülkeler arasındaki milli gelir ve gelir dağılımındaki adaletsizliğin ekonomik kararlara etki etmediği görülmüștür. Bu sonuç adalet olgusunun, kültürel farklılık sebebiyle, toplumdan topluma değișiklik gösterdiğini ve bu durumun da kișilerin ekonomik kararlarında farklılıklara sebebiyet verdiğini bize göstermektedir.

- Antropologların ilkel kabilelerde yaptıkları deneyler, modern kültürlerle ilkel kültürler arasındaki adalet algısı farkını net bir șekilde ortaya koyar. Illkel kabileler klasik ekonomik teoriye en uygun bir biçimde bencil (rasyonel) davranmakta, karșı tarafa çok düșük rakamlar teklif etmekte, ve teklif edilen en düșük rakamları bile tereddütsüzce kabul etmektedir. Bu da, ilkel kültürlerde sosyal normlar ve dayanıșma algısı fazla gelișmemiș olduğundan kișinin benmerkezci davranıșa daha yatkın olduğunu gösterir. Toplum geliștikçe, birey davranıșlarında toplumun baskısını daha fazla hissetmeye bașlar.

- Bireyin karșısındakinden beklentisi, kararını șekillendiren önemli etmenlerden biridir. Sosyal bir çevrede yașayan 
insan bașkalarının kendisi hakkında ne düșündüğünü önemser ve topum tarafından iyi algılanmak ister. Kiși ekonomik karar alırken bencil davranarak toplumun gözünden düssmek istemez. Bu yüzden birey ekonomik davranıșında bașkalarına da fayda sağlayarak, onların da aldığı kararlarda kendine fayda sağlayacağını umar. Bireyin içinde yașadığı toplum ne kadar sıkı ve ilișkiler ne kadar güçlü ise, beklenti olgusu da o kadar baskın olur.

- İnsan karșısındakinin kendisine benzer muamele edeceğini bilir. Eğer kiși karșısındakine adil ve cömert bir davranıș gösterirse, muhatabının da kendisine adil ve cömert davranıș göstereceğini umar. Karșısındakinden adaletsiz bir davranıș gören insan, muhatabını bu davranıșı dolayısı ile cezalandırmak ister. Bu açıdan karșılıklılık ilkesi bireyin ekonomik kararlarında geçerli olan bir unsurdur.

- Karar verirken insan muhatabının hareketinin sonucunu mu yoksa muhatabının niyetini mi önemser? Yapılan ültimatom oyunu deneyleri hem negatif hem de pozitif karșllıklılık (mütekabiliyet) davranıșlarında, kișinin karșısındakinin niyetine göre karar verdiğini göstermiștir. İnsanlar ekonomik davranıșlarında, karșılarındaki kișinin niyetini önemser ve bu niyete göre karar verir.

- Bireyler ekonomik kararlarında çeșitli davranıș modelleri (kuralları) çerçevesinde hareket eder. Katı eșitlikçi anlayıșa göre kișinin ekonomik refahtan aldığı pay çalıșması ve yeteneği ile orantılı olmamalı, herkes zenginliği eșit paylașmalıdır. Liberter bakıș ise kișinin yetenek ve çalıșmasından mesul olduğuna inanır; adil bir paylașım kișini ürettiği kadar kazanmasıdır. Liberal eșitlikçiler ise kișinin çalıșmasından sorumlu olduğuna ama yeteneğinin kendi kontrolünde olmadığına inanır; adil bir dağıım, yetenek farklılıklarını eșitlemeli ama çalıșma farklııklarını göz önüne almalıdır. Dolayısı ile farklı adalet anlayıșında olan ve adaletli davranmayı önemseyen insanlar, bakıș açıları çerçevesinde, ekonomik kararlarını farklı önceliklerle alabilir. 
- Aynı șekilde, saf bencil davranıșı benimseyen insanlar karar alırken diğerlerinin çıkarları ile ilgilenmez, tek odak noktaları kendi maddi çıkarlarıdır. Kendine hizmet eden davranıș biçiminde ise kiși kendi maddi çıkarının yanında, diğerlerinin çıkarlarını da düșünür. Kișinin beklentisi, diğerlerinin çıkarının kendi çıkarına hizmet etmesidir. Bu yüzden bu șekilde davranan bir insan karar verirken birden fazla etmeni göz önüne almak zorundadır.

- Toplum, kendi içindeki ișbirliğini teșvik ederek bireylerin refahını artırmayı amaçlar. Bireyin toplum içinde diğerleri ile ișbirliğine gidebilmesi için, diğer insanların sosyal tercihlerini kavraması lazımdır. Bu açıdan idrakin (anlayıșın) gelișmișlik derecesi, bireyin ekonomik kararlarına etki eder.

- İnsanın içinde bulunduğu rekabetin șiddeti ve maddi kaynağa duyduğu ihtiyacın büyüklüğü, bireyin ekonomik kararlarını sınırlı da olsa etkiler.

- Kișinin ekonomik alandaki bilgisi ekonomik kararlarını etkilememektedir.

- İnsanlar fiziksel açıdan etkileyici insanlara karșı daha cömert davranmaktadır. Kadınlar erkeklere nazaran, karșı cinslerine daha cömerttir. 


\section{KAYNAKÇA}

Jensen, K., Call, J., \& Tomasello, M. 2007, Ekim 8. Chimpanzees Are Rational Maximizers in an Ultimatum Game. www.sciencemag.org: http://wkprc. eva.mpg.de/pdf/2007/Jensen_Call_Tomasello_2007_chimps_ultimatum_ game.pdf adresinden alınmıștır.

Baldursson, F. M. 2006. Rent-seeking and fairness: The case of the Reykjavik Savings Bank. International Review of Law and Economics 26, s. 123-142.

Bereby-Meyer, Y., \& Niederle, M. 2005. Fairness in Bargaining. Journal of Economic Behavior \& Organization Vol. 56, s. 173-186.

Camerer, C. F. 2003. Behavioral Game Theory. Princeton University Press.

Cappelen, A. W., Hole, A. D., Sorensen, E. O., \& Tungodden, B. 2006, Ocak 13. The pluralism of fairness ideals: An experimental approach. Social Science Research Network: http://papers.ssrn.com/sol3/papers. cfm?abstract_id=875303 adresinden alınmıștır

Carmichael, F. 2005. A Guide to Game Theory. Essex: Pearson Education Limited.

Cox, J. C. 2004. How to identify trust and reciprocity. Games and Economic Behavior 46, s. 260-281.

Davis, M. D. 1983. Game Theory: A Nontechnical Introduction. New York: Dover Publications Inc.

Dixit, A., Skeath, S., \& Reiley, D. H. 2009. Games of Strategy, 3th ed. New York: W. W. Norton \& Company Inc.

Falk, A., Fehr, E., \& Fischbacher, U. 2008. Testing theories of fairness-Intentions matter. Games and Economic Behavior 62, s. 287-303.

Fisher, L. 2008. Rock, Paper, Scissors. Game Theory in Everyday Life. New York: Basic Books.

Forsythe, R., Horowitz, J. L., Savin, N. E., \& Sefton, M. 1994. Fairness in Simple Bargaining Experiments. Games and Economic Behavior 6, s. 347-369.

Güth, W., Schmittberger, R., \& Schwarze, B. 1982. An Experimental Analysis of Ultimatum Bargaining. Journal of Economic Behaviour and Organization 3, s. 367-388.

Henrich, J. 1998, Ekim 26. Does culture matter in economic behavior? Ultimatum Game Bargaining among the Machiguenga of the Peruvian Amazon. American Economic Review.

Hoffman, E., McCabe, K. A., \& Vernon, S. L. 1996. On Expectations and the Monetary Stakes in Ultimatum Games. International Journal of Game Theory, s. 289-301. 
Hoffman, E., McCabe, K., Shachat, K., \& Vernon, S. 1994, Kasım. Preferences, Property Rights, and Anonymity in Bargaining Games. Games and Economic Behavior Volume 7, Issue 3, s. 346-380.

Kirchsteiger, G. 1994. The role of envy in ultimatum games. Journal of Economic Behavior and Organization Vol.25, s. 373-389.

List, J. A., \& Cherry, T. L. 2000, Haziran. Learning to Accept in Ultimatum Games: Evidence from an Experimental Design that Generates Low Offers. Experimental Economics, s. 11-29.

Metin, S. 2014. Oyun Teorileri Ișığında Thomas Hobbes'un Sosyal Sözleșme Kuramının Analiz ve Yorumu. İstanbul Üniversitesi Hukuk Fakültesi Mecmuası, s. 235-264.

Myerson, R. B. 1999, Mart. Nash Equilibrium and the History of Economic Theory. Journal of Economic Literature, s. 1067-1082.

Oosterbeek, H., Sloof, R., \& van de Kuilen, G. 2004. Cultural Differences in UItimatum Game Experiments: Evidence from a Meta-Analysis. Experimental Economics, 7, s. 171-188.

Rabin, M. 1993, Aralık. Incorporating Fairness into Game Theory and Economics. The American Economic Review, s. 1281-1302.

Rizvi, S. A. 2003. Postwar Neoclassical Microeconomics. W. J. Samuels, J. E. Biddle, \& J. B. Davis içinde, A Companion to the History of Economic Thought, s. 377-394. Blackwell Publishing.

Rosenthal, E. C. 2011. Game Theory, The fascinating math behind decisionmaking. New York: Alpha Books.

Roth, A. E. 1995. Bargaining Experiments. J. H. Kagel, \& A. E. Roth içinde, Handbook of Experimental Economics, s. 253-342. Princeton University Press.

Schotter, A., Weiss, A., \& Zapater, I. 1996. Fairness and Survival in Ultimatum and Dictatorship Games. Journal of Economic Behavior \& Organization Vol. 31, s. 37-56.

Stanley, T. D., \& Tran, U. 1998. Economics Students Need Not Be Greedy: Fairness and the Ultimatum Game. Journal of Socio-Economics, Volume 27, No. 6, s. 657-664.

Suleiman, R. 1996. Expectations and fairness in a modified Ultimatum game. Journal of Economic Psychology 17, s. 531-554.

Takagishi, H., Kameshima, S., Schug, J., Koizumi, M., \& Yamagishi, T. 2010. Theory of mind enhances preference for fairness. Journal of Experimental Child Psychology 105, s. 130-137.

Ubeda, P. 2014. The consistency of fairness rules: An experimental study. Journal of Economic Psychology 41, s. 88-100. 
